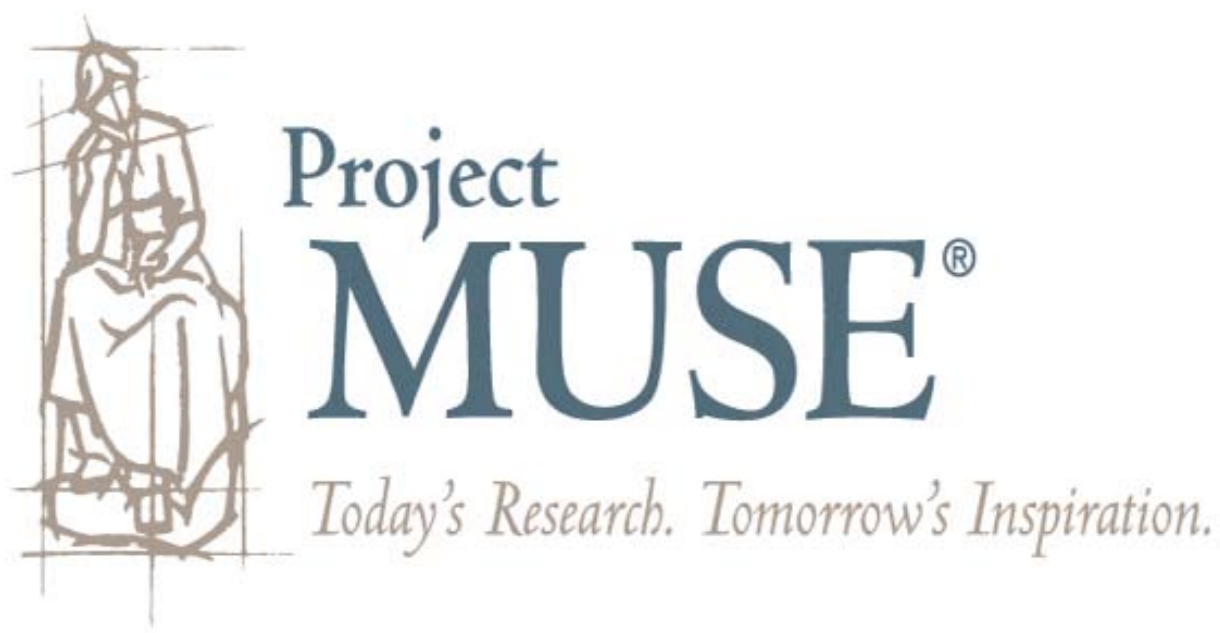




\title{
Imperial Scholars and Minority Nationalisms in Late Imperial and Early Soviet Russia
}

\author{
Vera TOLZ
}

The late imperial period in Russia was marked by intense debates about how to achieve social, political, and, in some instances, cultural cohesion within the context of the empire's multi-ethnicity and multiculturalism. To use our contemporary terminology, we can define the challenge that faced Russian politicians and intellectuals as a resolution of tension between the country's imperial structures and the forces of modern nationalism. ${ }^{1}$ Among the various actors whose role in developing the new thinking about the management of the empire has recently been attracting increasing attention are imperial scholars. Particularly since the 1880 s, some of them began advancing, through their research, various integrationist projects as liberal Moscow anthropologists searched for a definable "imperial race" on the territory of the Russian state, whereas linguists explicitly related their own work on Russian

Research for this article was funded by the United Kingdom's Arts and Humanities Research Council.

1 Andreas Kappeler, "The Ambiguities of Russification," in Orientalism and Empire in Russia, ed. Michael David-Fox, Peter Holquist, and Alexander Martin (Bloomington, IN: Slavica Publishers, 2006), 227-33; Daniel Brower, "Along the Borderlands of the Empire," in Orientalism and Empire in Russia, 349-60; Robert Crews, For Prophet and Tsar: Islam and Empire in Russia and Central Asia (Cambridge, MA: Harvard University Press, 2006); Paul Werth, At the Margins of Orthodoxy: Mission, Governance, and Confessional Politics in Russia's Volga-Kama Region (Ithaca, NY: Cornell University Press, 2002); Adeeb Khalid, The Politics of Muslim Cultural Reform: Jadidism in Central Asia (Berkeley: University of California Press, 1998); Austin Jersild, "From Savagery to Citizenship: Caucasian Mountaineers and Muslims in the Russian Empire," in Russia's Orient: Imperial Borderlands and Peoples, 17001917, ed. Daniel Brower and Edward Lazzerini (Bloomington: Indiana University Press, 1997), 101-14; Theodore Weeks, Nation and State in Late Imperial Russia: Nationalism and Russification on the Western Frontier, 1863-1914 (DeKalb: Northern Illinois University Press, 1996); Bruce Grant, In the Soviet House of Culture: A Century of Perestroikas (Princeton, NJ: Princeton University Press, 1995), 66; Yuri Slezkine, Arctic Mirrors: Russia and the Small Peoples of the North (Ithaca, NY: Cornell University Press, 1994), 113-29. 
and Ukrainian languages to their visions of the future Russia. ${ }^{2}$ The tsarist government, however, often disregarded the opinions of academics, particularly those who were known to be critical of autocracy and of the cultural and administrative Russification of minorities. Thus the main contribution of scholars in facilitating the management of the empire's borderlands in the late imperial period is seen as being limited mostly to the development of the new nationality-based categories of classification of imperial subjects which bureaucrats utilized to control the borderlands more efficiently. ${ }^{3}$ It is widely assumed that it was in the early Soviet period that the (former) imperial experts on Russia's ethnic minorities began to play a truly significant role in nation-building (natsional'noe stroitel'stvo in Soviet terminology) among the population of the borderlands. ${ }^{4}$

More broadly, it is also widely accepted that, even though the late imperial government began to utilize ethnic markers to organize politics, ${ }^{5}$ the process of the formation of nations among eastern and southern minorities (with the exception of Armenians and Georgians) falls within the Soviet period. ${ }^{6}$ This article contributes to a still limited body of research that focuses on the ways in which prerevolutionary discourses of nationhood and modernity actually exercised a major impact on the early Soviet nationalities policies. Adeeb Khalid has articulated in a particularly forceful manner the argument that these policies cannot be understood without knowledge of the developments in the last decades of the old regime. His work has challenged the established view that local peoples in Turkestan had not thought in national terms before the Bolshevik government initiated the national delimitation of Central Asia in the 1920s. ${ }^{7}$

${ }^{2}$ Marina Mogilner, "Russian Physical Anthropology in Search of 'Imperial Race': Liberalism and Modern Scientific Imagination in the Imperial Situation," Ab Imperio, no. 1 (2007): 191-223; see also her Homo imperii: Istoriia fizicheskoi antropologii v Rossii (Moscow: NLO, 2008); and Juliette Cadiot, "Russia Learns to Write: Slavists, Politics, and the Struggle to Redefine Empire in the Early Twentieth Century," Kritika 9, 1 (2008): 135-97.

3 Juliette Cadiot, "Searching for Nationality: Statistics and National Categories at the End of the Russian Empire (1897-1917)," Russian Review 64, 3 (2005): 440-55; and Khalid, The Politics of Muslim Cultural Reform, 197.

${ }^{4}$ Francine Hirsch, Empire of Nations: Ethnographic Knowledge and the Making of the Soviet Union (Ithaca, NY: Cornell University Press, 2005).

5 Charles Steinwedel, "To Make a Difference: The Category of Ethnicity in Late Imperial Russian Politics, 1861-1917," in Russian Modernity: Politics, Knowledge, Practices, ed. David Hoffmann and Yanni Kotsonis (Houndmills, UK: Macmillan, 2000), 70, 81.

${ }^{6}$ Ronald Suny, The Revenge of the Past: Nationalism, Revolution, and the Collapse of the Soviet Union (Stanford, CA: Stanford University Press, 1993); Terry Martin, The Affirmative Action Empire: Nations and Nationalism in the Soviet Union, 1923-1939 (Ithaca, NY: Cornell University Press, 2001).

${ }^{7}$ Khalid, The Politics of Muslim Cultural Reform; and his "Backwardness and the Quest for Civilization: Early Soviet Central Asia in Comparative Perspective," Slavic Review 65, 2 (2006): 231-51. 
Another case of a link between the formation of new identities among non-Russian minorities in the late imperial and the early Soviet periods was noted in 1977 by Isabella Kreindler and further studied recently by Austin Jersild. Both scholars have argued that there was a degree of similarity between Lenin's policies on nationalities and the approach to the Christianization of small minority groups in the Volga region, formulated in the 1860 s by the Orthodox missionary Nikolai Il'minskii. Under the influence of Romantic nationalism Il'minskii became convinced that the Christianization and eventual Russification of minorities was possible only if those minorities respected their local customs. ${ }^{8}$ The Bolshevik leaders, however, never directly referred to Il'minskii's experiment; and in its essence, the missionary's plans for the minorities differed significantly from the early Soviet visions. The promotion of ethno-cultural distinctions among these minorities by Il'minskii had very narrow limits, particularly in comparison with the Soviet project of sub-state nation-building. Il'minskii intensely feared the appearance among the minorities of people possessing what at the time was called "national consciousness" (natsional'noe samosoznanie).? The schools set up by Il'minskii actually facilitated this development, but it certainly was not his plan. ${ }^{10}$ Thus Il'minskii's activities fit well with a common perception among contemporary scholars that, when certain modernizing projects of the imperial elites encouraged the emergence of nationally minded activists and national movements in the colonial domains, this happened unwittingly, rather than being the imperial elites' intention. ${ }^{11}$

This article looks at a group of Russian imperial scholars who at the turn of the 20th century - at least a decade and a half before the 1917 revolutionsconsciously began to play an active role in fostering "national consciousness" among certain minority groups (inorodtsy) in Russia's eastern and southern

8 Austin Jersild, "Faith, Custom, and Ritual in the Borderlands: Orthodoxy, Islam, and the 'Small Peoples' of the Middle Volga and the North Caucasus," Russian Review 59, 4 (2000): 512-29; Isabelle Kreindler, “A Neglected Source of Lenin's Nationalities Policy," Slavic Review 36, 1 (1977): 86-100.

9 The expression "national consciousness" meant a sense of belonging to a specific community defined by various ethno-cultural attributes, including common language and historical memories. For a similar definition of the term in contemporary scholarship, see Miroslav Hroch, "From National Movement to the Fully-Formed Nation: The Nation-Building Process in Europe," in Becoming National: A Reader, ed. Geoff Eley and Ronald Suny (New York: Oxford University Press, 1996), 61.

10 Wayne Dowler, Classroom and Empire: The Politics of Schooling Russia's Eastern Nationalities, 1860-1917 (Montreal: McGill-Queen's University Press, 2001), 152.

${ }_{11}$ See, for instance, Nicholas Dirks, Castes of Mind: Colonialism and the Making of Modern India (Princeton, NJ: Princeton University Press, 2001), 226-27; Mark Cornwall, "The Habsburg Monarchy: 'National Trinity' and the Elasticity of National Allegiance," in What Is a Nation? Europe 1789-1914, ed. Timothy Baycroft and Mark Hewitson (Oxford: Oxford University Press, 2006), 175; and David Cannadine, Ornamentalism: How the British Saw Their Empire (London: Penguin, 2002), 141, 164. 
borderlands. ${ }^{12}$ These are the scholars whose role in the development of the early Soviet nationalities policies has been discussed by Francine Hirsch. ${ }^{13}$ They were eminent Orientologists of the Imperial/Russian/Soviet Academy of Sciences and former revolutionary populists who turned into ethnographers during their exile in Siberia and Russia's Far North. This article shows that by analyzing prerevolutionary and early Soviet encounters between these scholars and representatives of the inorodtsy communities which they studied we can acquire important new insights into the following issues: the relationship between the integrationist projects articulated by imperial scholars in the prerevolutionary period and early Soviet nationalities policies; the patterns of formation of the nationally minded intellectuals from among the inorodtsy and the ways in which these intellectuals acted as intermediaries between the imperial culture and local communities in the eastern and southern borderlands; the role of networks established in the last decades of the old regime between imperial scholars and representatives of the inorodtsy communities in the politics of identity during the 1905 Revolution and after 1917; and the contribution of not only imperial scholars but also representatives of inorodtsy to the construction of imaginings of the empire's non-European minorities as ethno-cultural nations both before and after 1917. The nature of the encounter between these imperial scholars and the inorodtsy representatives also raises the issue of the specificity of the Russian imperial experience.

The imperial scholars discussed here were a product of two interconnected developments in Russian academia which started in the 1880s. The first was the creation of the "new school" of Russian Orientology by Academician Viktor Rozen, Russia's leading Arabist and dean of the Oriental Faculty of St. Petersburg University between 1893 and $1902 .{ }^{14}$ The second was the articulation in the 1880 s by the internationally acclaimed art historian Nikodim Kondakov of a holistic vision of "Russian culture" as a product of centuries of interaction between the empire's Slavic and non-Slavic nationalities, including the population of the Caucasus and Central Asia. In Kondakov's view, shared by Rozen, these joint cultural activities led to the creation of a "single people" (edinyi narod) in the territory of the Russian empire. ${ }^{15}$ The institutional framework for pursuing the study of the formation

${ }^{12}$ For a discussion of the usage of the word inorodtsy, see John Slocum, "Who, and When, Were the Inorodtsy? The Evolution of the Category of 'Aliens' in Imperial Russia," Russian Review 57, 2 (1998): 173-90.

${ }_{13}$ Hirsch, Empire of Nations. On the same issue, see also Nikolai Ssorin-Chaikov, The Social Life of the State in Subarctic Siberia (Stanford, CA: Stanford University Press, 2003); and V. M. Alpatov, 150 iazykov i politika (Moscow: Institut vostokovedeniia RAN, 2000).

${ }_{14}$ Vera Tolz, "European, National, and (Anti-)Imperial: The Formation of Academic Oriental Studies in Late Tsarist and Early Soviet Russia," Kritika 9, 1 (2008): 53-81.

15 I. Tolstoi and N. Kondakov, Russkie drevnosti v pamiatnikakh iskusstva (St. Petersburg: Tipografiia Ministerstva putei soobshcheniia, 1889), III. 
of this "culture" was the Oriental Department of the Russian Imperial Archaeological Society, headed by Rozen since 1885. The two groups of scholars who are protagonists in this story participated in the activities of this department. The first group were Rozen's disciples, who arguably became Russia's most famous Orientologists: the foremost archaeologist of the Caucasus and a highly controversial linguist, Nikolai Marr; a leading expert on Islam, Vasilii Bartol'd; the eminent Buddhologist and long-term permanent secretary of the Academy of Sciences, Sergei Ol'denburg; and another famous Buddhologist, Fedor Shcherbatskoi. Like their mentor, they were self-defined "liberal Russian patriots." This self-definition in the prerevolutionary period applied even to Marr, who, significantly for the development of his views, combined his identity as an imperial scholar with his experience of living as a "native" (his mother was a Georgian of low social origin) in the colonial conditions of the Caucasus. ${ }^{16}$ Another group of scholars who played an important role in this story were populist revolutionaries, particularly Dmitrii Klements and Lev Shternberg, who became eminent specialists on the inorodtsy in Siberia and the Far North. They were helped by Rozen and his disciples in the pursuit of their academic aspirations, being thus subjected to the influences of the "new school" of Russian Orientology. ${ }^{17}$

I show in this article that at the turn of the 20th century, these imperial scholars developed particularly close professional and personal relationships with representatives of the minority groups in Siberia and in the Caucasus that did not have a tradition of literacy in their vernacular languages until the Soviet period. These minorities included the Buriats in Siberia and the Abkhazians in the Caucasus, who occupied an intermediate position between small minority groups in Russia's Far North, widely perceived at the time as "lacking culture," and the nationalities with their own ancient high literary cultures, such as the Armenians and Georgians. ${ }^{18}$ The "intermediate" groups of inorodtsy discussed here possessed elites who were literate in Russian and either Mongolian, in the case of the Buriats, or Georgian and Arabic, in the case of the Abkhazians. In the last prerevolutionary decades, representatives of these minorities became receptive to the ideas of Romantic nationalism which were in circulation in the empire and thus began imagining their own communities as nations. I argue in this article that these imaginings were a

${ }_{16}$ N. I. Platonova, "Nikolai Iakovlevich Marr-arkheolog i organizator arkheologicheskoi nauki," Arkheologicheskie vesti, no. 5 (1998): 371-82.

17 I. I. Popov, “D. A. Klements: Ego zhizn' i deiatel'nost'," in D. A. Klements, Iz proshlogo (Leningrad: Kolos, 1925), 55-56, 61-62; S. A. Shternberg, "Lev Iakovlevich Shternberg i Muzei antropologii i etnografii Akademii nauk," in Sbornik Muzeia antropologii i etnografi AN SSSR (Leningrad: Izdatel'stvo Akademii nauk SSSR, 1928), 39.

${ }^{18}$ L. Ia. Shternberg, "Inorodtsy: Obshchii obzor," in Formy natsional'nykh dvizhenii v sovremennykh gosudarstvakh, ed. A. Kastelianskii (St. Petersburg: Obshchestvennaia pol'za, 1910), 533. 
product of the encounter between imperial scholars and these communities' representatives. Facilitated by specific developments in the academic studies of the Caucasus and of Buddhism, the networks that emerged out of the prerevolutionary interactions between the imperial scholars and the inorodtsy representatives and the results of their collective efforts in the late imperial period laid the foundation for the early Soviet nation-building projects.

The relationship between imperial scholars and learned "natives" in the production of new knowledge about Europe's colonial domains has been a subject of intense debate since the publication of Benedict Anderson's, Bernard Cohn's, and Edward Said's works on the impact of "colonial knowledge," seen by these scholars as "an important part of the colonial project of control and command" (Cohn), on how colonial subjects have perceived their own communities as nations. ${ }^{19}$ Post-Orientalist scholarship is concerned with the role of the colonized peoples in the production of this colonial knowledge. Three ways of theorizing this role, developed largely on the basis of the material about South Asia, can be identified. Following Cohn, some scholars speak of the "dramatic appropriation" and silencing of "native" voices in knowledge production. According to this interpretation, in the colonial context, where the imperial elites possessed the sole power to define what was acceptable and what was not, it is inappropriate to perceive representatives of colonized societies as active agents in the production of colonial knowledge. ${ }^{20}$ The opposite view has been put forward particularly forcefully by Eugene Irschick who described the perceptions of Indian society articulated in the colonial period as a product of a "dialogue" between the "natives" and the British in which the two sides "equally participated." ${ }^{11}$ Ischick has been careful, however, to point out that the equality of the contribution of both sides is something that could be identified by contemporary scholars retrospectively, rather than being a view shared by actors at the time. The intermediate position between these approaches is offered by Kapil Raj, who, while proposing to bring "coproduction" of modern science by Europeans and the colonial people "back to center stage," rejects the concept of a dialogue, on the grounds that in the

19 Benedict Anderson, Imagined Communities (London: Verso, 1991); Bernard Cohn, Colonialism and Its Forms of Knowledge (Princeton, NJ: Princeton University Press, 1996); Cohn, An Anthropologist among the Historians and Other Essays (New York: Oxford University Press, 1988); Edward Said, Culture and Imperialism (New York: Knopf, 1993).

${ }^{20}$ Nicholas Dirks, "Colonial Histories and Native Informants: Biography of an Archive," in Orientalism and the Post-Colonial Predicament, ed. Carol Breckenridge and Peter van der Veer (Philadelphia: University of Pennsylvania Press, 1993), 279-313; Gyan Prakash, Another Reason (Princeton, NJ: Princeton University Press, 1999); Talad Asad, ed., Anthropology and the Colonial Encounter, 7th ed. (Atlantic Highlands, NJ: Humanities Press, 1995), 16.

${ }^{21}$ Eugene Irschick, Dialogue and History (Berkeley: University of California Press, 1994); Thomas Trautmann, "Hullabaloo about Telugu," South Asia Research 19, 1 (1999): 53-70. See also C. A. Bayly, Empire and Information: Intelligence Gathering and Social Communication in India, 1780-1870 (Cambridge: Cambridge University Press, 1996). 
context of South Asia, the division of labor between "the natives" and imperial actors was stratified and "well hierarchized." 22

In the late imperial and early Soviet context, the role of representatives of non-European minorities in the production of new knowledge about the Russian empire's borderlands has been studied much less than in the case of South Asia. The existing research indicates that there was no single pattern of developments across the Russian empire and the early Soviet state. According to Nikolai Ssorin-Chaikov, in the elaboration of ethnographic imaginings of the small minority group of Russia's Far North, the Evenki, the role of the "indigenous population" was very limited. Soviet ethnographers, who implemented new nationalities policies among the Evenki in the 1920s, insisted that they were restoring "old traditions" of collective work. The Evenki elders could hardly be described as co-producers of these "invented traditions"; instead they were expected to legitimize the early Soviet initiatives by claiming that they recognized in them genuine indigenous ways. ${ }^{23}$ In relation to the same period, Hirsch analyzed the role of the local elites of larger non-Russian communities in the former imperial borderlands at the time of the creation of the Soviet Union. ${ }^{24}$ In that story, the local elites appropriated the language of nationality from the Bolshevik regime to advance their own political agendas and to manipulate to their own advantage the imaginings of their own communities designed by the Bolshevik government and (former) imperial experts. Khalid's above-mentioned work gives the greatest agency to the local elites in Central Asia, the Jadids, in producing national visions for the region. In his account, contacts between the local elites and Russian imperial scholars in prerevolutionary and early Soviet Central Asia played a minimal role, as the Jadids borrowed broad notions of nationhood and modernity from the Ottoman empire and the Volga Tatars. ${ }^{25}$

In the story presented in this article a great significance, including major political implications, is attributed to the encounter between representatives of certain inorodtsy groups in the eastern and southern borderlands and Russian imperial scholars. The imperial scholars provided an important source of the ideas of nationalism for the representatives of the local communities that this article analyzes. For their part, the inorodtsy representatives, after the turn of the 20th century, were highly important agents in the production of the notions of modernity and nationhood in relation to their own communities and after 1905, they began exercising a formative impact on the perceptions of the imperial scholars. In the first years of the 20th century, the imperial scholars discussed here started to claim that they were empowering

22 Kapil Raj, "Colonial Encounters and the Forging of New Knowledge and National Identities: Great Britain and India, 1760-1850," Osiris 15, 1 (2001): 119-34.

23 Ssorin-Chaikov, The Social Life of the State in Subarctic Siberia, 47-53.

24 Hirsch, Empire of Nations.

${ }^{25}$ Khalid, The Politics of Muslim Cultural Reform. 
their inorodtsy associates to a degree that was unusual in the European imperial context. This article considers whether this claim of Russia's specificity was at all justified.

\section{Empire and Nation in the Perceptions of Imperial Scholars}

The scholars' view of minorities was a mixture of imperial and national thinking. They subscribed to the idea of Russia's civilizing mission in Asia, based on the perception of the superiority of European civilization; and within this framework they assigned to themselves the mission of spreading what they called "European scientific thinking" among the peoples of "Russia's Orient" and involving these people in the "discovery" of their own past and indigenous traditions. ${ }^{26}$ At the same time, the fact that scholars, influenced by the Romantic tradition, imagined the world as divided into culturally defined nationalities provided important ideological foundations for their research. Even if one agrees with the view of postcolonial scholarship that imperial scholars' historical research "colonized the past" of the colonial subjects, ${ }^{27}$ it is essential to acknowledge that, in the period reviewed here, European scholars focused particularly on ancient history because, as one Russian researcher put it, through it the "innate ethnic characteristics of the people were manifested." 28 Even though linguistic research was utilized by imperial governments, scholars claimed that the study of languages was important because the "innate spiritual individuality of the people, above all, is manifested in the language they have created." 29 Ethnography was indeed used for colonial purposes, ${ }^{30}$ yet initial ethnographic studies often focused on customs of peasant communities as repositories of the "national traditions" of Europe itself. ${ }^{31}$ Because the ideas of nationalism permeated European scholarship during the period discussed here, Orientologists could routinely use concepts and approaches first developed in the study of European peoples while studying the peoples of the East. Thus the largest ethnographic expedition organized in the 1890s for the study of Siberia's inorodtsy (the Sibiriakov expedition) had as its main stated aim the "discovery

${ }^{6}$ V. V. Bartol'd, "Rech' pered zashchitoi dissertatsii," in his Sochineniia (Moscow: Nauka: 1963), 1: 610.

27 Dirks, Castes of Mind, 194.

${ }^{28}$ P. K. Uslar, Etnografiia Kavkaza: Iazykoznanie. Chechenskii iazyk (Tiflis: Kantseliariia Glavnonachal'stvuiushchago grazhdanskoiu chastiiu na Kavkaze, 1888), 6.

29 P. K. Uslar, "Kharakteristicheskie osobennosti kavkazskikh iazykov," in Sbornik svedenii o kavkazskikh gortsakh, no. 9, otd. 1 (Tiflis: Izdatel'stvo Kavkazskogo gorskogo upravleniia, 1876): 12; Nikolai Solov'ev, "Iazyk, kak osnova natsional'nosti," in Otechestvennye zapiski, no. 1 (1866): 480-81.

30 Dirks, Castes of Mind, 43.

31 Nathaniel Knight, "Science, Empire, and Nationality: Ethnography in the Russian Geographical Society, 1845-1855," in Imperial Russia: New Histories for the Empire, ed. Jane Burbank and David Ransel (Bloomington: Indiana University Press, 1998), 127. 
of the national characters of the peoples." 32 For Marr, the aim of the studies of the Caucasus was "to uncover, in chronological order, their [nationalities'] unique manifestations." ${ }^{3}$

Due to this preoccupation with "nationality" in their research, and because the contiguous Russian empire made the integration of small subject nationalities into the metropole a genuine possibility, Russian Orientologists began applying to the inorodtsy not only the methods with which Russian history and culture were studied but also theories of integration which had first been developed in relation to the Russian population. In the 1870s, the Russian press began publishing articles which argued that, to develop the Russian population's national loyalty to the entire state-framed community, one should first develop among them a thorough knowledge of and love for the history and cultural tradition of their place of birth and permanent residence. It was argued that one could relate to the entire Russian fatherland (otechestvo) only through a strong affiliation with one particular locality or the "small homeland" (malaia rodina). Furthermore, local identities and their links with a pan-Russian identity should be fostered by a local history component in the school curriculum, the creation of local museums, and the involvement of the public in collecting information about their localities. ${ }^{34}$ Whereas in Germany and France people had a developed pride in and knowledge of the traditions of their regions, ${ }^{35}$ in Russia this sense of regional identification was weak, the Russian activists argued, assigning to themselves the task of rectifying the situation. ${ }^{36}$ These ideas were originally articulated most vocally by regionalist intellectuals (oblastniki) in Siberia and the provinces of European Russia with reference to the Russian-speaking population.

As Yuri Slezkine has noted, the place of the inorodtsy in the vision of the Siberian regionalists was ambiguous. For them, the inorodtsy represented Siberia's indigenous roots, yet they were also the manifestation of the region's

32 Quoted in Osvoboditel'noe dvizhenie v Rossii i iakutskaia politicheskaia ssylka, part 2 (Iakutsk: Iakutskii nauchnyi tsentr Sibirskogo otdeleniia Akademii nauk SSSR, 1990), 14.

${ }^{33}$ N. Ia. Marr, "K voprosu o zadachakh armianovedeniia," Zhurnal Ministerstva narodnogo prosveshcheniia (hereafter ZhMNP), July 2/324 (1899): 242.

${ }_{34}$ D. Klements, "Mestnye muzei, ikh znachenie v provintsial'noi zhizni," Sibirskii sbornik, no. 2 (1892): 1-35, traces the history of the "small homeland" concept in Russia from the 1870 s on. See also V. Iu. Grigor'ev, "O znachenii mestnykh muzeev voobshche i minusinskogo v chastnosti," Izvestiia Krasnoiarskogo podotdela Vostochno-Sibirskogo otdela Imperatorskogo russkogo geograficheskogo obshchestva (hereafter VSOIRGO) 1, 4 (1902): 3-5. See also N. Skalozubov, Organizatsiia obshchestvennykh sil $v$ tseliakh izucheniia Sibiri (St. Petersburg: Al'tshuler, 1912).

35 On the relationship between regional and national identities in Europe, see Celia Applegate, A Nation of Provincials: The German Idea of Heimat (Berkeley: University of California Press, 1990); and Alon Confino, The Nation as a Local Metaphor: Württemberg, Imperial Germany, and National Memory (Chapel Hill: University of North Carolina Press, 1997).

36 Klements, "Mestnye musei," 17. 
backwardness. ${ }^{37}$ A leader of Siberian regionalists and a champion of the rights of Siberia's indigenous population, Nikolai Iadrintsev, nevertheless described the inorodtsy as "inferior races," mixing with whom had a negative impact on the physical and mental qualities of Russian settlers. ${ }^{38}$ But Iadrintsev's was not the only way of viewing the situation of the inorodtsy through the prism of the ideology of the "small homeland" movement. In a manner resembling that in which the Hungarian writer and politician Baron József Eötvös hoped that the emerging national aspirations of minorities in Austria-Hungary could be turned into manifestations of regional patriotism conducive to the preservation of imperial state structures, Marr, in his 1899 speech to mark his appointment to a post in Armenian Studies at St. Petersburg University, applied the ideas of the "small homeland" movement to the non-Russian subjects of the empire. ${ }^{39}$ Marr observed:

As for the Armenians and the Georgians, in particular, the state has all the more reason to regard Armenian and Georgian Studies as an excellent tool, because it is clear that they develop and strengthen enlightened love and respect for the small homeland. Who can deny the fact, which is axiomatic to me, that one who is indifferent to the plight of one's own region cannot deeply embrace a more abstract and complex feeling for the fatherland. ${ }^{40}$

A number of other Orientologists shared Marr's view. Bartol'd stressed, with reference to the Muslim population of Russia, that it would be a mistake not to promote studies of local cultures and not to preserve monuments of Islamic history and art out of fear that this would "strengthen local peculiarities, undermining spiritual fusion" with the Russians. The opposite would be the case, he thought. ${ }^{41}$ Klements argued that if the "ethno-cultural awareness ... of the steppe people were to grow, they would get closer and closer to Russia." ${ }^{\prime 2}$ In sum, if the minorities became more knowledgeable about and proud of the histories and ethno-cultural particularities of their "small homelands," they would be in a better position to partake in panRussian activities and would become better integrated into the pan-Russian state-framed community without losing their distinctiveness.

\section{The Origins of Nationally Minded "Native" Intelligentsia}

This acceptance of the "small homeland" ideology by a group of imperial Orientologists had significant political implications. In a major departure

37 Slezkine, Arctic Mirrors, 114-19.

38 N. M. Iadrintsev, Sibir' kak koloniia (St. Petersburg: Izdatel'stvo Sibiriakova, 1882), 31.

39 On Eötvös, see Cornwall, "The Habsburg Monarchy," 178.

40 Marr, "K voprosu o zadachakh armianovedeniia," 244. See also the same idea expressed in N. Ia. Marr, “Kavkazskii kul'turnyi mir i Armeniia," ZhMNP, pt. 57 (June 1915): 329.

${ }^{41}$ Mir Islama, no. 1 (1912): 375.

42 D. Klements, “Pessimizm na buriatskoi pochve," Sibirskie voprosy, no. 10 (1907): 22. 
from the attitudes of the Orientalists with a missionary agenda, such as Il'minskii, the scholars who subscribed to the "small homeland" ideology viewed the possible appearance of the nationally minded intelligentsias among the inorodtsy not with fear but with great anticipation. Moreover, they made a conscious contribution to the fostering of this intelligentsia.

It is widely accepted that the emergence of nationally minded intelligentsias in the colonies was largely due to growing social mobility and the creation of European-type educational systems in the colonies and the subsequent frustrated social mobility of individuals with such an education. ${ }^{43}$ The establishment of various schools for the inorodtsy since the 1860s and growing access to Russia's higher educational institutions increased the number of representatives of eastern minorities with a European-type education. ${ }^{44}$ Yet this greater access to education could not in itself stimulate a particular desire among these individuals to study and preserve the cultural heritage of their own ethnic communities, which became, in most cases, their first step toward acting as "national leaders" of these communities. Indeed, if we look at the biographies of the people who became leaders of the inorodtsy movements in 1905 and, after the October Revolution, acquired leading posts in the governments of the newly created ethnic autonomies of the Soviet state among small minority groups in Siberia and the Caucasus, we see that they originally entered higher educational institutions to acquire middle-class or elite jobs in law, medicine, or diplomacy and that their interest in national issues predated any experience of professional discrimination. ${ }^{45}$ In many cases, this interest arose through encounters with Orientologists who employed representatives of inorodtsy studying in St. Petersburg as research assistants in their fieldwork in the eastern borderlands. The encounter with Orientologists was, of course, not the only source of national visions for the inorodtsy representatives. It was, however, a highly significant one.

In the period reviewed here, colonial subjects were regularly used as informants by European Orientologists. They were usually not seen as scholars in their own right, however; their findings fed into works published solely under the names of European scholars. ${ }^{46}$ Russian Orientologists

43 Anderson, Imagined Communities, 140; Hroch, "From National Movement to the FullyFormed Nation," 66-67; Ronald Suny and Terry Martin, eds., A State of Nations: Empire and Nation-Making in the Age of Lenin and Stalin (New York: Oxford University Press, 2001), 52.

${ }^{44}$ Dowler, Classroom and Empire.

45 N. N. Koz'min, “Tuzemnaia intelligentsiia Sibiri,” Sibirskaia zhivaia starina, no. 1 (1923): 72-89; G. Ts. Tsybikov, Izbrannye trudy (Novosibirsk: Nauka, 1991), 1: 10-33; D. I. Gulia, Materialy po abkhazskoi grammatike (Sukhumi: Narkompros Abkhazskoi SSR, 1927); M. Khvartskiia, Andrei Maksimovich Chochua (Tibilisi: Sabchota Sakartvelo, 1981), 17, 53, 127-28.

46 Dirks, Castes of Mind, 105; Dirks, "Colonial Histories and Native Informants"; Sylvia Vatuk, "Shurreef, Herklots, Crooke, and Qanoon-E-Islam: Constructing an Ethnography of 'the Moosulmans of India,'” South Asia Research 19, 1 (1999): 5-28. 
claimed that their aim was to empower the "natives" in the production of Orientalist knowledge, and in some instances this was indeed the case. ${ }^{47}$ This was particularly true in the study of the Caucasus and Buddhology, due to the internal developments in these disciplines in the first decades of the 20 th century.

Between 1899 and 1910, Marr revised the agenda of the academic studies of the Caucasus by postulating the need to research minority groups without established literary traditions in the vernacular languages. ${ }^{48}$ He suggested doing the kind of research that would significantly increase scholars' dependence on "native informants" in preference to the method used in traditional Oriental Studies, which largely relied on the philological interpretation of textual traditions. ${ }^{49}$ In the course of his regular visits to Abkhazia for archaeological and linguistic work, Marr established close ties with members of the "Bzybsk Committee" for the spread of education among the Abkhazians, particularly Andrei Chochua, Samson Chanba, and Darmit Gulia, all future political and cultural leaders in Abkhazia in the 1920s. These people were already familiar with the ideas of nationalism, particularly via Georgian sources. ${ }^{50}$ But in the late imperial period, together with Marr, they began imagining the Abkhazians as a separate nation. In 1912, just four years after Marr had proclaimed the existence of the specific branch of "Japhetic languages," his Abkhaz associate Petr Charaia published a book in St. Petersburg, On the Relationship of Abkhaz to Japhetic Languages, with Marr's introduction, in which he claimed the existence of Japhetic elements in the Abkhaz language, and that it predated the Georgian language. ${ }^{51}$

\footnotetext{
47 See, for instance, Mukhammad Ali Kazem-Bek's article in Sankt-Peterburgskie vedomosti, no. 91 (1857), quoted in A. K. Rzaev, Ocherki ob uchenykh i mysliteliakh Azerbaidzhana XIX veka (Baku: Maarif, 1969), 9-10.

48 N. Ia. Marr, "Akademiia Nauk i izuchenie Kavkaza," Sankt-Peterburgskii filial Arkhiva Rossiiskoi akademii nauk (PF ARAN) f. 800, op. 1, d. 1409.

49 The critique of the philological method and the emerging appreciation of the role of non-literate groups in cultural production were not limited to Russia. Similar trends were noticeable in German and Austrian scholarship, of which Russian scholars were well aware. Revisionism in Germany took somewhat different forms and had very different outcomes. See Suzanne Marchand, "The Rhetoric of Artifacts and the Decline of Classical Humanism: The Case of Josef Strzygowski," History and Theory 33, 4 (1906): 130.

${ }^{50}$ Literacy in Georgian was widespread in Abkhazia. On Georgian intellectuals' impact on developments in Abkhazia in the late 19th and the early 20th century, see Sh. D. InalIpa, Abkhazy (Sukhumi: Alashara, 1965), 160-65; Inal-Ipa, Stranitsy abkhazskoi literatury (Sukhumi: Alashara, 1980), 6-24; and G. A. Dzidzariia, Formirovanie dorevoliutsionnoi abkhazskoi intelligentsii (Sukhumi: Alashara, 1979).

51 P. Charaia, Ob otnoshenii abkhazskogo iazyka k iafeticheskim (St. Petersburg: Tipografiia Imperatorskoi akademii nauk, 1912). See also Charaia's correspondence with Marr (PF ARAN f. 800, op. 3, d. 1032, particularly ll. 4-5 ob.).
} 
Similarly revisionist developments took place in Russian Buddhology. ${ }^{52}$ At the turn of the 20th century, Ol'denburg and Shcherbatskoi articulated a new approach to the study of ancient Buddhist texts based on the "living oral traditions" of Buddhism..$^{53}$ Shcherbatskoi's The Theory of Knowledge and Logic according to the Latest Buddhist Teaching, published in St. Petersburg in the first decade of the 20th century, tentatively questioned European Buddhology's reliance on the philological method in interpreting old Buddhist texts. ${ }^{54}$ Instead, Shcherbatskoi suggested that the interpretations of contemporary learned Buddhists (particularly lamas) should be used to facilitate their understanding. Shcherbatskoi's approach was novel and, in fact, ran counter to the dominant trend in Buddhist Studies in Europe at the time. ${ }^{55} \mathrm{Ol}^{\prime}$ denburg, for his part, argued from the 1890s on that Europeans should take the interpretations of "learned Easterners" of their own cultures into account. ${ }^{56}$

This new approach led $\mathrm{Ol}^{\prime}$ denburg and Shcherbatskoi to believe that Russian Buriats would be particularly well equipped to conduct research in Buddhist Studies. Their choice fell on Gombozhab Tsybikov, Banzar Baradiin, and Tsyben Zhamtsarano, future leaders of the Buriat movement during the 1905 Revolution and leading figures in "national construction" in Buriatia in the 1920s. These Buriats came to study at the Oriental Faculty at St. Petersburg in order to enter the imperial diplomatic service. ${ }^{57} \mathrm{Ol}^{\prime}$ denburg and Scherbatskoi, however, saw these students' future somewhat differently.

The Petersburg Orientologists offered Tsybikov and Baradiin special training to equip them for research trips to Tibet, which was closed to European scholars. To much acclaim, both eventually presented their findings, which were not simply descriptive but also interpretive, to the academic community in St. Petersburg. ${ }^{58}$ Meanwhile, since 1902, Zhamtsarano had been conducting research into Buriat folklore, collaborating, in particular, with $\mathrm{Ol}^{\prime}$ denburg and

22 T. V. Ermakova, Buddiiskii mir glazami rossiiskikh issledovatelei XIX-pervoi treti XX veka (St. Petersburg: Nauka, 1998), 249-75.

53 On Western Buddhologists' far more ambivalent attitude toward relying on "native" interpretations of Buddhist texts than the one Shcherbatskoi was proposing, see Donald Lopez, ed., Curators of the Buddha: The Study of Buddhism under Colonialism (Chicago: University of Chicago Press, 1995), 3-4. Lopez's book does not take the developments in Russian Buddhology into account.

${ }_{54}$ F. I. Shcherbatskoi, Teoriia poznaniia i logiki po ucheniiu pozdneishikh buddistov, parts 1 and 2 (St. Petersburg: Gerol'd, 1903, 1909).

55 Lopez, ed., Curators of the Buddha.

56 Zapiski Vostochnogo otdeleniia Russkogo arkheologicheskogo obshchestva (hereafter ZVORAO), no. 9 (1896): 304.

57 Tsybikov, Izbrannye trudy, 1: 7-8.

58 B. B. Baradiin, "Puteshestvie v Lavran," Izvestiia IRGO 14, 4 (1908): 183-232. Tsybikov gave a talk about his expedition at a meeting of the Geographical Society in St. Petersburg in 1903. For various technical reasons, the full report was published only in 1918: see Tsybikov, Izbrannye trudy, 1: 30-31. 
Klements. At the time, Klements was setting up the Ethnographic Department of the Russian Museum in St. Petersburg, conscripting inorodtsy students in the Russian capital to assist him in the collection of ethnographic material. His arguments about why his recruits should be interested in such work were fully in line with the "small homeland" ideology. Ethnographic research would strengthen the inorodtsy communities' pride in their cultural and historical traditions, allowing the inorodtsy to survive as culturally distinct communities and, at the same time, to integrate better into the pan-Russian framework, Klements maintained..$^{59}$ As is clear from the correspondence among Baradiin, Zhamtsarano, and $\mathrm{Ol}^{\prime}$ denburg, by 1904 these Buriats became instrumental in helping $\mathrm{Ol}^{\prime}$ denburg and Shcherbatskoi realize their new research agenda. Their fieldwork reports explained to the Petersburg scholars different approaches to Buddhism among contemporary Buddhists; the former also facilitated the scholars' contacts with Buriat lamas. ${ }^{60}$

$\mathrm{Ol}^{\prime}$ denburg and Shcherbatskoi, in turn, facilitated the relationship between their Buriat students and Agvan Dorzhiev, a Buriat from the Transbaikal region of Russia who had been a close associate of the Dalai Lama since the late 1880s. ${ }^{61}$ Maintaining close ties with the Russian government and transmitting pro-Russian and later pro-Soviet sympathies in Tibet, Dorzhiev was far from merely a tsarist and Soviet agent. Influenced by his experience in Tibet, he had his own vision for the Buriats of Russia within a pan-Mongolian Buddhist theocratic state with its center in Tibet. A friend of Ol'denburg and Shcherbatskoi since 1898, Dorzhiev developed ideas which had a major impact on visions of the "Buriat national revival." 62

\section{The 1905 Revolution-A Turning Point}

During the 1905 Revolution, movements that spoke the language of "national self-determination" (natsional'noe samoopredelenie) (mostly within the framework of the Russian imperial state) emerged among the inorodtsy in the imperial borderlands. Among the inorodtsy groups in Siberia and the Caucasus, the leaders of these movements were often former research assistants of Orientologists. Experts with conservative views and an interest in missionary work were highly alarmed by these developments. ${ }^{63}$ The liberals, in contrast, were delighted,

59 A. Mergen, "D. A. Klements i sibirskie inorodtsy," Izvestiia VSOIRGO, no. 45 (1917): 243.

${ }^{60}$ Baradiin's correspondence with Ol'denburg, PF ARAN f. 208, op. 3, d. 28, 11. 10-11 ob., 23, 40-42 ob.; and Zhamtsarano's correspondence with Ol'denburg, ibid., d. 210, 11. $4,30-34$.

${ }^{61}$ See Ol'denburg's correspondence with Dorzhiev, ibid., d. 196, 2811.

${ }^{62}$ A. I. Andreev, Khram Buddy v severnoi stolitse (St. Petersburg: Nartang, 2004), 25-27; John Snelling, Buddhism in Russia (Shaftesbury: Element, 1993).

63 A. M. Pozdneev, "Otchet o poezdke k terskim, ural'skim i orenburgskim kalmykam," Arkhiv Sankt-Peterburgskogo instituta vostochnykh rukopisei RAN (Archive of SPbIVR RAN) f. 44, op. 1, d. 60, 1. 97; and his “O novom buriat-mongol'skom alfavite," ibid., d. 69, 1l. 1-5. Pozdneev was professor of Mongolian at St. Petersburg University. His study 
seeing the formation of these movements as a vindication of their view that the appearance of nationally minded intelligentsias among the minorities as well as a growing interest among the inorodtsy in their own ethno-cultural heritage was a "natural" development which would facilitate their integration into the Russian state. ${ }^{64}$ During the days of the first Russian revolution, the imperial scholars were in regular contact by post with their former students, who now turned into political activists and regularly informed their former teachers about the developments in the inorodtsy communities. ${ }^{65}$ They expected the imperial scholars' support for the cause of the "national self-determination" of the inorodtsy and, indeed, received it. $\mathrm{Ol}^{\prime}$ denburg helped with the establishment of Buriat and Kalmyk publishing houses and facilitated a favorable coverage of his former Buriat students' activities in the St. Petersburg press. Klements encouraged Zhamtsarano to set up a Buriat-language press. ${ }^{66}$ Similar developments took place in the Caucasus. ${ }^{67}$

Liberal scholars' attitude toward what they saw as a sign of "national awakening" (their term) among the inorodtsy was reflected most radically in Shternberg's writings. His two 1910 essays on the subject are still used as an important source on inorodtsy politics during the 1905 Revolution and its aftermath. ${ }^{68}$ Yet, despite the seeming sophistication of his analysis, Shternberg's account is highly biased. Among the inorodtsy there emerged different movements offering competing visions for the future development of the communities on whose behalf they claimed to speak. In the case of the Buriats, Shternberg sided with one particular group, uncritically accepting all its arguments. In his post-1905 publications about the "Buriat national revival," Klements did exactly the same. ${ }^{69}$ Thus before 1905, even though some inorodtsy started to work and disseminate their findings as scholars in their own right within Russian academia, their work contributed to but did not form the imaginings of the inorodtsy cultures. After 1905, some inorodtsy began to shape perceptions of their own communities both among their own people and among imperial scholars in significant ways. ${ }^{70}$

in a theological seminary ensured his interest in missionary goals throughout his life. See Ermakova, Buddiiskii mir glazami rossiiskikh issledovatelei, 94.

${ }^{64}$ See, in particular, Shternberg, "Inorodtsy," 566.

65 PF ARAN f. 208, op. 3, d. 210, 1l. 16-19, 21 ob., 22-25 ob., 28-29, 30-34; d. 28, 11. 23-23 ob.

${ }^{66}$ Ibid., d. 210, 1l. 16, 18. See also Dorzhiev's correspondence with Ol'denburg, ibid., d. 196, 11. 18-19; and A. A. Vigasin et al., eds., Istoriia otechestvennogo vostokovedeniia (Moscow: Vostochnaia literatura, 1997), 369.

${ }_{67}$ B. A. Kaloev, V. F. Miller-kavkazoved (Ordzhonikidze: Severo-Osetinskoe knizhnoe izdatel'stvo, 1963), 33, 37.

${ }^{68}$ Shternberg, "Inorodtsy"; and his "Buriaty," in Formy natsional'nykh dvizhenii, 603-24.

${ }^{69}$ Klements, "Pessimizm na buriatskoi pochve."

70 There is a parallel between the case discussed here and the description by Robert Crews of how members of the Russian imperial elites "managed Islam" by siding with one or another 
According to Shternberg, during the revolution there appeared among the inorodtsy signs of the transformation of a nationality (narod) into a nation (natsional'nyi kollektiv). ${ }^{71}$ The scholar singled out the role of the "native intelligentsia"-that "astonishing spiritual phenomenon"-in transforming economic and social grievances into national and political ones. "This intelligentsia, which on the basis of deep knowledge of the past [emphasis added] could see clearly the horizons of the future, could be born only under the influence of European enlightenment, i.e., the medium of Russian culture and education," he continued. ${ }^{73}$ While arguing that certain ideas were shared by many inorodtsy movements, Shternberg described a plurality of views on specific issues between and within the inorodtsy communities. He was particularly interested in the Buriats, among whom the emergence of the nationally minded intelligentsia was rapid. Buriat leaders disagreed about what form of self-government was suitable; about which parts of the "Buriat tradition" were viable in the contemporary world; if different Buriat tribes had different traditions; and about what the Buriat literary language should be, if people spoke different Buriat dialects.

A particularly significant division resulting from Russian policies lay between the Transbaikal Buriats, among whom the Tibetan form of Buddhism was the main religion, and the Irkutsk Buriats, who were placed in a separate administrative district and subjected to greater Christianization. By 1905, Buddhists were in the minority among the Irkutsk Buriats. In 1905, Transbaikal Buriats were the first to start couching their demands in national terms. Their leader Zhamtsarano, alongside other Buriats with close links to imperial scholars, argued for a vision of the "Buriat nation" as Buddhist and for the Buriat literary language to be based on the Halha dialect of Mongolian in which a literary tradition existed and with which literate Buddhist Buriats of Transbaikal'e were familiar. For the proposed literary Buriat language they also advocated adopting a script produced by Dorzhiev on the basis of the old Mongolian alphabet. In 1905 and 1906, during his research trips to the Irkutsk region, Zhamtsarano attempted to propagate his national vision there. Leaders of the Irkutsk Buriats protested against Zhamtsarano's ambition to speak in the name of all the Buriats of Russia, offering instead a concept of the Buriat

group of Muslims who debated religious issues ("Empire and the Confessional State: Islam and Religious Politics in Nineteenth-Century Russia," American Historical Review 108, 1 [2003]: 50-83). In contrast to the cases analyzed by Crews, however, the imperial experts possessed not political but intellectual power.

71 Shternberg, "Inorodtsy," 533, 536, and 546. The scholar defined the inorodtsy as "groups of people for whom European culture is completely alien or those who have partaken in it only in a very limited way" (533).

72 Ibid., 554.

73 Ibid. Shternberg admitted that the intelligentsia among the Muslim population of Russia was exposed to the ideas of nationalism not only through Russian sources but also through the Ottoman empire and Egypt (560). 
nation, where religion was relegated to the private sphere and literacy was to be developed on the basis of the Latin script. ${ }^{74}$ Zhamtsarano branded his opponents assimilationists and police informants and claimed that their views, in contrast to his own, had little public resonance. ${ }^{75}$

Without citing any evidence, Shternberg suggested that the "Buriat intelligentsia and ordinary masses" (even in the Irkutsk region) offered "passionate support" to Zhamtsarano. ${ }^{76} \mathrm{He}$ also alleged, at times quoting Zhamtsarano almost verbatim, that Zhamtsarano's opponents performed "police functions." 77 Even before Shternberg, Klements interfered in the press debate between Zhamtsarano and his main Irkutsk opponent, fully siding with the former and accusing the latter of ignoring the Buriat-Mongolian "indigenous traditions." ${ }^{\prime \prime}$ In turn, $\mathrm{Ol}^{\prime}$ denburg's main source of information about the developments among the Buriats was also Zhamtsarano. It is his version of events in Siberia that $\mathrm{Ol}^{\prime}$ denburg helped promote in the St. Petersburg press. $^{79}$

The Transbaikal Buriats who attempted to speak in the name of all the Buriats of Russia had, of course, personal ties with the Russian Orientologists, which the Irkutsk Buriats did not have. ${ }^{80}$ There were, however, other reasons for the Russian scholars' particular sympathy for Zhamtsarano's views. In these scholars' opinion, "national awakening" had to be stimulated based on knowledge of the past. References to the "indigenous historical and cultural traditions" which were believed to be still alive and relevant, the "living antiquity" (zhivaia starina), as the scholars called it, permeated their work. Thus Zhmatsarano's vision for the Buriats, based on "knowledge of the past," fitted better with the scholars' perception of how a nation should be perceived than did the proposals of the Irkutsk Buriats, who were largely preoccupied with contemporary realities. The scholars' particular sympathy for Zhamtsarano's views was also related to the fact that they shared his understanding of the

${ }_{74}$ M. Bogdanov, "Buriatskoe 'vozrozhdenie,” Sibirskie voprosy, no. 3 (1907): 38-49.

75 Ts. Zhamtsarano, "Buriaty i osvoboditel'noe dvizhenie," Sibirskie voprosy, no. 7 (1909): 6-7.

76 Shternberg, "Buriaty," 623. For such claims by Zhamtsarano, see his "Buriaty i osvoboditel'noe dvizhenie," 6.

77 Shternberg, "Buriaty," 622.

78 Klements, "Pessimizm na buriatskoi pochve," 8, 11, 15-16. Slezkine, Arctic Mirrors, 123, argued that when in 1905 "regionalist movements made something of a comeback ... the aliens were effectively off the agenda." This was true for the "wandering tribes" of the North, who were the focus of Slezkine's study. Yet, as indicated by the case of Klements, who was an active participant in the revived regionalist movement post-1905, "nomadic and sedentary" inorodtsy of Siberia were high on the agenda of these Russian activists.

79 PF ARAN f. 208, op. 3, d 28, 11. 16-19, particularly ll. 16 and 18.

80 The leader of the Irkutsk Buriats, Mikhail Bogdanov, studied in Tomsk and in Germany. For his biography, see Robert A. Rupen, "The Buriat Intelligentsia," Far Eastern Quarterly, 15, 3 (1956): 386. On Zhamtsarano's contacts with Klements, see, for instance, their correspondence in 1905, Archive of SPb IVR RAN f. 28, op. 2, d. 119, 411. 
role of Buddhism among the Buriats. ${ }^{81}$ For Zhamtsarano, Buddhism offered the best "moral framework" for the Buriats. From the time of his first fieldwork among the Buriats, when his task was to study shamanic beliefs and practices, he had been sending letters to $\mathrm{Ol}^{\prime}$ denburg that negatively depicted the impact of shamanism and "artificial conversions to Orthodox Christianity" (iskustvennye okreshcheniia) on the moral fiber of the Buriat communities. ${ }^{82}$ Similarly, for Shcherbatskoi and Ol'denburg, Buddhism was a more sophisticated and therefore more "progressive" religion than shamanism and a "native" religion of the Buriats in contrast to Christianity. ${ }^{83}$

In their support for Zhamtsarano, the imperial scholars betrayed little awareness of the extent to which the "indigenous traditions" they believed he promoted were a product of imperial policies and academic research. Even though Shternberg admitted that Buddhism spread particularly rapidly among the Transbaikal Buriats as a result of the policies of Empress Elizabeth, and even though he did not dispute the argument that among the Irkutsk Buriats Buddhism had historically never been prevalent, he nevertheless described conversions to Buddhism in that region in 1905 as a "return to the old faith." ${ }^{4}$ A similar view of Zhamtsarano's "proselytizing" activities was articulated by $\mathrm{Ol}^{\prime}$ denburg. ${ }^{85}$ The scholars followed Zhamtsarano in calling Dorzhiev's alphabet the "native script" for all the Buriats, even though literacy in Mongolian was limited to Transbaikal'e. ${ }^{86}$

Both Zhamtsarano and his Irkutsk opponents argued for the creation of a Buriat nation within Russia and for the integration of the Buriats into a pan-Russian cultural space. They saw the possible place of the Buriats within that space differently, however. While leaders of the Irkutsk Buriats argued in favor of the Buriats' equal participation in Russia's political institutions, Zhamtsarano (under the influence of Dorzhiev) saw their central role as falling under Russian foreign policy. Following Dorzhiev, Zhamtsarano proposed that the Buriats should act as transmitters of European culture in

${ }^{81}$ Klements, "Pessimizm na buriatskoi pochve," 9-10; Shternberg, "Buriaty," 605-6; S. F. Ol'denburg, "Buddiiskoe iskusstvo Indii," Izvestiia Rossiiskoi imperatorskoi akademii nauk 14, 2 (1901): 217.

82 PF ARAN f. 208, op. 3, d. 210, 1l. 4, 6-6 ob. The quote is from 1. 4.

${ }^{83}$ Klements, "Pessimizm na buriatskoi pochve," 9-10; Shternberg, "Buriaty," 605-6;

$\mathrm{Ol}^{\prime}$ denburg, "Buddiiskoe iskusstvo Indii," 217.

84 Shternberg, "Buriaty," 605.

85 PF ARAN f. 208, op. 3, d. 28, 1. 23.

${ }^{86}$ For a similar example of the scholars' apparent lack of reflection on their own role in the construction of "indigenous traditions" for the minorities of Russia's North in the 1920s, see Nikolai Ssorin-Chaikov, "Representing 'Primitive Communists': Ethnographic and Political Authority in Early Soviet Siberia," in Russian Empire: Space, People, Power, ed. Jane Burbank, Mark von Hagen, and Anatolyi Remnev (Bloomington: Indiana University Press, 2007), 268-94. See also Crews, "Empire and the Confessional State," 77-78. 
the East. ${ }^{87}$ Under the influence of their Buriat associates, Shternberg and Klements articulated the same view. ${ }^{88}$

Zhamtsarano, Dorzhiev, Tsybikov, and Baradiin, ${ }^{89}$ all of whom in 1905 and in the aftermath of the revolution became active propagators of national visions among the Buriats, carried out intelligence and other functions for the imperial government during their fieldwork among the Buriats and their trips abroad. ${ }^{90}$ Yet by the early 20 th century, what they were doing was also informed by their view of themselves as working on behalf of the imagined Buriat nation; and they used the opportunities imperial service offered to advance the Buriats' interests and prestige, as they saw it, in a larger Mongolian and Buddhist community. Shternberg and Klements, both opponents of the tsarist regime who served prison sentences for revolutionary activities, in their own minds justified the role they supported for the Buriats within Russia and among the Mongol steppe not from the pragmatic position of the imperial intelligence services but through the lofty ideas of the special raison d'être of the Buriat and Russian nations.

\section{New Visions after 1905}

Notable for the growing activities of various leaders of the inorodtsy groups in articulating different visions of their communities as nations, the decade and a half prior to the October Revolution was also marked by developments in views and perceptions of Orientologists that would affect the imaginings of minorities in the eastern borderlands as newly formed nations in the 1920s.

Particularly important in this context were Marr's views, both because of his bold revision of the main assumptions of European Orientology and because of their impact in the Soviet period. In his lectures in Sukhumi, the capital of Abkhazia, in 1916, Marr argued in favor of the centrality of small minority groups, widely seen as backward and inferior, in the development of European civilization. ${ }^{91}$ While at the turn of the 20th century Shternberg detected elements of communist relationships in the life of the minorities of Russia's North, thus paving the way for their praise in the Soviet period as

\footnotetext{
${ }^{87}$ Rupen, "The Buriat Intelligentsia," 385, 388, 390-93.

${ }^{88}$ Klements, "Pessimizm na Buriatskoi pochve," 22; Shternberg, "Buriaty," 623.

89 Baradiin, without opposing Dorzhiev's Mongolian script as did Bogdanov, was nevertheless interested in designing a Latin-based script for the Buriat dialect which he himself spoke. He became the first Buriat scholar to make such an attempt. See Orient, no. 1 (1992): 117.

90 A. M. Reshetov, "Nauka i politika v sud'be Ts. Zh. Zhamtsarano," Orient, no. 2-3 (1998): 5-55. The fact that Tsybikov gathered important information for the tsarist government during his trip to Tibet is reflected in his "Buddist-palomnik u sviatyn' Tibeta," in his Izbrannye trudy, 1.

91 N. Ia. Marr, "Kavkazoveden'e i abkhazskii iazyk," ZhMNP, no. 5 (1916): 1-27, repr. in N. Ia. Marr, Etapy razvitiia iafeticheskoi teorii (Leningrad: GAIMK, 1933). The pagination is given according to the GAIMK reprint.
} 
proto-communist, ${ }^{92}$ Marr developed an elaborate argument about the cultural superiority of inorodtsy such as the Abkhazians over ancient Greeks and modern Europeans who historically had dominated them. The folklore of minorities without established vernacular literary traditions, according to Marr, offered a "more solid and rich source" for the study of "living antiquity" and the "indigenous pre-Christian and pre-Islamic traditions in the Caucasus" than did the literatures of people with established literary traditions, such as the Georgians and Armenians, whose literatures, influenced from outside by the world's dominant cultures (Greeks, Romans, and Europeans), were "artificial." "Living antiquity," which small minorities managed to preserve, was so important because it reflected the foundational stages of the history of the Caucasus-that is, the time when the region, according to Marr, became the original homeland of his invention, the "Japhetic people." These people produced the "most ancient culture in the world," from which "our European civilization" eventually developed. ${ }^{94}$ Thus, rather than being peoples outside history, the minority groups were central to the creation of European civilization.

At the same time, $\mathrm{Ol}^{\prime}$ denburg and Shcherbatskoi depicted Buddhism as fully compatible with, and facilitating the spread of, "European enlightenment" among its adherents, a view also enthusiastically propagated by Dorzhiev. ${ }^{95} \mathrm{Ol}^{\prime}$ denburg and Shcherbatskoi rejected the argument of other

92 Grant, In the Soviet House of Culture, 53.
${ }_{93}$ Marr, "Kavkazoveden'e i abkhazskii iazyk," 59-60.
${ }^{9}$ Ibid., 60, 67, and 73. A comprehensive survey of Marr's views is presented in Yuri Slezkine, "N. Ia. Marr and the National Origin of Soviet Ethnogenesis," Slavic Review 55, 4 (1996): 826-62. Slezkine focuses on the absurdity of Marr's theories. He connects the wide support among representatives of small minority groups for Marr's theories in the 1920s and the early 1930s with Marr's relentless deconstruction of the concepts of "nation," "race," and "ethnicity" (849). Although most of Marr's linguistic theories were indeed absurd, some of the scholar's broad assumptions about the state of Orientology in Europe, about the constructed nature of the categories "nation" and "ethnicity" and about the social role of language, actually anticipated the conclusions of Western academic research from the 1960s on. Rather than being linked to his questioning of traditional definitions of "nation" and "ethnicity," Marr's popularity among representatives of the minority groups in the Caucasus, Siberia, and European Russia seems to be connected with his ideas about their cultural greatness.

${ }_{95}$ Shcherbatskoi, Teoriia poznaniia $i$ logika po ucheniiu pozdneishikh buddistov; S. F. $\mathrm{Ol}^{\prime}$ denburg et al., "Zapiska ob uchenykh trudakh professora Fedora Ippolitovicha Shcherbatskogo," Izvestiia Rossiiskoi akademii nauk, series VI, vol. XII, no. 16 (1918): 1712-22. A key contribution to this revisionism was made by Shcherbatskoi's student Otto Rozenberg. See O. O. Rozenberg, Trudy po buddizmu (Moscow: Nauka, 1991); and his "O ponimanii vostochnoi dushi," in Neizdannye raboty O. O. Rozenberga, ed. T. V. Ermakova (Moscow: Nauka, 1990), 113-19. For a comparable construction of the image of Zen as fully compatible with science and rational thinking by representatives of the Meiji New Buddhism in Japan and the impact of their ultimately nationalist agenda on Western intellectuals, see Robert H. Sharf, “The Zen of Japanese Nationalism,” History of Religion 33, 1 (1993): 1-43. See also Judith Snodgrass, Presenting Japanese Buddhism in the West (Chapel Hill: University of North Carolina Press, 2003). 
Russian Buddhologists that Buddhism was an obstacle to the integration of the Buriats. ${ }^{96}$ They also contrasted what they described as the West European negative view of Tibetan Buddhism to their own positive perception of it. ${ }^{97}$

Against these developments in their own disciplines and under the direct influence of their inorodtsy collaborators, the imperial scholars constructed a more favorable image of the inorodtsy than had previously been the case. In the 1860s and 1870s, Siberian regionalists agreed that, "whatever the future," the present state of the inorodtsy "was very low." 98 At the turn of the century, the Russian press debated the negative impact on Russian settlers of

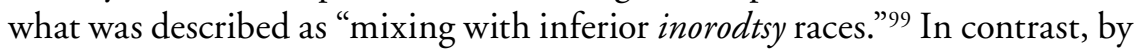
the end of the first decade of the 20th century liberal Russian Orientologists and ethnographers began to argue that some inorodtsy groups were morally and mentally superior to the Russian masses. According to Shternberg, Islam "puts them [the masses of Muslims] intellectually incomparably higher than the surrounding Russian population." ${ }^{100}$ For Klements, the Buriat clan system was in no way inferior to Russian peasant communes. ${ }^{101}$ This more positive view of the inorodtsy came at the same time as the Orientologists intensified their arguments that Russian identity united the achievements of the Eastern and Western civilizations. In Ol'denburg's words, Russia's inorodtsy who turned into scholars offered the best evidence of "this cultural unification of the West and the East for achieving common goals." 102 The correspondence between inorodtsy representatives and imperial scholars seems to suggest that the idea about the moral and "spiritual" superiority of the inorodtsy communities over Russian settlers and about the harmful impact of the latter on the inorodtsy had, in fact, been picked up by the scholars from their inorodtsy associates. The latter began promoting this idea in their

96 V. P. Vasil'ev, Religii Vostoka (St. Petersburg: V. S. Balashov, 1873), 4-6, 10; S. F. $\mathrm{Ol}^{\prime}$ denburg, "Pamiati Vasiliia Pavlovicha Vasil'eva i o ego trudakh po Buddizmu," Izvestiia Rossiiskoi Akademii nauk, series VI, vol. XII, no. 7 (1918): 531-48. Pozdneev, "Otchet o poezdke k terskim, ural'skim i orenburgskim kalmykam," 1, 97. See also Pozdneev's report for the Department of Spiritual Affairs of the Provisional Government (Archive of SPb IVR RAN f. 44, op. 2, d. 6, 1. 94). Like Vasil'ev and Pozdneev, Il'minskii believed that shamanism and paganism among the minorities in the Volga region were preferable to Islam. On Il'minskii's views, see Jersild, "Faith, Custom, and Ritual in the Borderlands," 516-17.

97 See B. Ia. Vladimirtsov, "Buddizm v Tibete i Mongolii," in Ermakova, Buddiiskii mir glazami rossiiskikh issledovatelei, 229-30.

98 Slezkine, Arctic Mirrors, 119.

99 Willard Sunderland, "Russians into Iakuts? 'Going Native' and Problems of Russian National Identity in the Siberian North, the 1870s-1914," Slavic Review 55, 4 (1996): 806-25.

100 Shternberg, "Inorodtsy," 542.

101 D. Klements, “Zametki o kochevom byte,” Sibirskie voprosy, no. $49 / 52$ (1908): 50.

102 S. F. Ol'denburg, "Ot redaktsii," in Tsybikov, Izbrannye trudy, 1: 31. 
very first fieldwork reports. ${ }^{103}$ Similarly, Klements's positive assessment of the clan system was strongly influenced by Zhamtsarano's views. ${ }^{104}$

Last but not least, the years before the 1917 revolutions witnessed the activization of Orientologists' campaigns in the spirit of the "small homeland" movement for the onsite preservation of historic monuments, the creation of local museums, and the establishment of higher educational and research institutions in the eastern borderlands. ${ }^{105}$ These campaigns intensified significantly after the events of 1905 made scholars believe in the possibility of wider societal involvement in the above activities. ${ }^{106}$ After 1905 and during World War I in particular, scholars such as $\mathrm{Ol}^{\prime}$ denburg and Marr increasingly maintained that their approach to the study of Eastern cultures displayed a greater respect for local people's needs and "native" knowledge than did the work of their West European counterparts. ${ }^{107}$ They needed only a government that would better support them in their aspirations.

\section{Imperial Scholars, Local Representatives, and Soviet National Construction}

After the February Revolution, Orientologists attempted to push forward the initiatives on which the tsarist government had been reluctant to act, including the establishment of the Historical-Archaeological Institute of the Caucasus and a university in Tbilisi. ${ }^{108}$ After October 1917, new opportunities arose. Hirsch has demonstrated the role imperial scholars played in the formation of the Soviet Union by offering their expertise to achieve the delimitation of boundaries between different nationalities and ethnic groups. While presenting the formation of the USSR as a joint venture of the central government, imperial scholars, and local elites, Hirsch focuses mostly on the impact of debates about "the census, the map, and the museum" on the policies of the central government. In Khalid's account of the politics in early

103 PF ARAN f. 208, op. 3, d. 210, 1. 2 ob, 1. 3 ob.

104 Ibid., 1. 4 ob.

105 Vera Tolz, "Orientalism, Nationalism, and Ethnic Diversity in Late Imperial Russia," Historical Journal 48, 1 (2005): 137-40, 144-45.

106 S. F. Ol'denburg in ZhMNP, 340, 3/4 (1902): 47-51; V. V. Bartol'd in Turkestanskie vedomosti, no. 33 (1902): 9, and in Turkestanskie vedomosti, no. 165 (1906): 10.

107 N. Ia. Marr, "Kavkazskii kul'turnyi mir i Armeniia," ZhMNP 57, 6 (1915): 327; and S. F. Ol'denburg, "Ekspeditsiia D. A. Klementsa v Turfan v 1898," Izvestiia VSOIRGO, no. 45 (1917): 111. During the war, German scholars made not-dissimilar criticisms of the scholarship and imperialist policies in the East of the Entente states, including Russia, and presented Germany as the only "true friend of Islam" and a liberator of the Orient. See Gottfried Hagen, "German Heralds of Holy War: Orientalists and Applied Oriental Studies," Comparative Studies of South Asia, Africa, and the Middle East 24, 2 (2004): 149.

108 "Zapiska akademika N. Ia. Marra o Kavkazskom istoriko-arkheologicheskom institute," and "Doklad akademika N. Ia. Marra o podgotovitel'noi deiatel'nosti po otkrytiiu Kavkazskogo istoriko-arkheologicheskogo instituta," Izvestiia Rossiiskoi akademii nauk, series IV, no. 13 (1917): 963-94 and 1000-6. 
Soviet Central Asia, in contrast, the key players are the local elites and the Bolsheviks, whereas the role of former imperial scholars is not considered. ${ }^{109}$

This section focuses on how various initiatives put forward by the imperial Orientologists and their associates from the borderlands affected the formation of national communities among the Buriats and the Abkhazians in the 1920s. Against the backdrop of the relative decentralization that continued until 1927, local elites and their patrons among the Orientologists often played a decisive role in the articulation of the cultural parameters of sub-state nation-building, borrowing extensively from the arsenal of the prerevolutionary ideas outlined above. As a result, various ethnic groups and nationalities which the new Soviet regime actively tried to mold into modern Soviet nations were imagined as firmly rooted in their ancient and medieval past. The new world was to be built on the destruction of the old. The old, however, was the tsarist regime, particularly that of the late imperial period, which scholars and representatives of eastern minorities were equally happy to criticize. Yet from the point of view of the scholars and their local associates, it was to be built on the incorporation of a glorified "living antiquity," which they had been "recovering" together since prerevolutionary days.

The collapse of the tsarist government and the eventual establishment of Soviet rule propelled former research assistants of the imperial scholars to positions of political power. In Buriatia, Baradiin served as commissar of education, Tsybikov was in charge of setting up mass primary and secondary educational systems, and Zhamtsarano worked for the Commissariat of Education in Buriatia and was a key figure in the creation of the Mongolian People's Revolutionary Party, thus continuing to fulfill his prerevolutionary ambition to achieve a leading position for the Buriats among the Mongol peoples. ${ }^{110}$ Dorzhiev continued to campaign for his vision of a pan-Mongolian Buddhist state, establishing close ties with the Soviet Commissariat of Foreign Affairs. ${ }^{111}$ In Abkhazia after 1921, Marr's research associates Chochua and Chanba led the Abkhaz Commissariat of Public Enlightenment and Gulia became the country's leading scholar and writer.

Many imperial scholars and members of local elites, especially those who led local commissariats of education, had, particularly in the early postrevolutionary years, strong reservations about Bolshevik rule. Both groups, however, were mostly complementary about Bolshevik nationalities policies. ${ }^{112}$ In addition, former imperial scholars, newly appointed local

109 Khalid, The Politics of Muslim Cultural Reform, 291-300; and his "Backwardness and the Quest for Civilization."

110 A. Kallinikov, "U istokov mongol'skoi revoliutsii," Khoziaistvo Mongolii 3, 10 (1928): 65-68.

111 Andreev, Khram Buddy v severnoi stolitse, 96-99.

112 See, for instance, V. V. Bartol'd, "Otchet o komandirovke v Turkestan," in his Sochineniia (Moscow: Nauka, 1966), 6: 260. 
leaders, and the new government shared a belief in the scientific management of a multinational state and agreed on the necessity of modernization entailing participation in the technological and cultural advancement of Europe. ${ }^{113}$ Yet the views that underpinned scholars', local representatives', and the Soviet regime's perception of the long-term goals of sub-state nation-building also differed substantially.

First, diverging strongly from the Soviet leadership, former imperial scholars and their local associates, now in charge of educational and cultural matters in their newly created autonomous regions, took a positive view of religion and allocated an important role to it in nation-building. Second, their sense of working, above all, for the "recovery" of an objectively existing "ancient heritage," of which the masses only needed to be made aware in order to start thinking and acting nationally, did not disappear as a result of their participation in the process of Soviet national construction. It is telling that in 1930, when scholars were expected to become involved in the campaign to fight "survivals of the past" (perezhitki proshlogo) reflected in "backward customs and traditions," 114 Marr, who at first glance would appear to be a leader of this fight, demonstrated his unease regarding the campaign, which in fact was aimed against what scholars like him had previously exalted as manifestations of "living antiquity." Talking to local leaders in Udmurtia about "survivals" in their ethnic autonomous region, Marr could not bring himself to say that they should be eradicated (as demanded by the political leadership in Moscow); after all, he had hitherto argued that these "survivals" were repositories of civilizational greatness. Marr therefore suggested that the negative impact of the "survivals" could be overcome through their scholarly study with the help of his Japhetic theory, rather than through eradication. ${ }^{15}$ Thus in the 1920s, through various local initiatives, former imperial scholars and their associates among the local elites introduced elements into national construction that were at odds with the long-term goals and intellectual assumptions of leading Bolshevik officials in Moscow.

Imaginings of the "Buriat nation" in the 1920s took particularly interesting forms through Dorzhiev's bold visions and the revisionist approach of Shcherbatskoi's school to the study of Buddhism. The two sides were united by the view that Buddhist Buriats could present an example of a successful union of the "Western" and "Eastern" spiritual and intellectual traditions within the pan-Russian framework. In 1923, at the time of the creation of the Buriat-Mongol Autonomous SSR as part of the RSFSR, most of the ASSR's newly appointed leaders viewed Buddhism as their "national religion" and positively assessed the role of datsans and perceived lamas as part of Buriatia's

${ }_{113}$ Hirsch, Empire of Nations, 44, 47, and 59.

${ }_{114}$ For a description of this campaign, see ibid., 246-58.

115 N. Ia. Marr, "Iazykovaia politika iafeticheskoi teorii i udmurtskii iazyk," in his Izbrannye raboty (Leningrad: GAIMK, 1933), 1: 272-84, esp. 284. 
nascent intelligentsia. ${ }^{16}$ The Buriat literary language was to be based on the Halha dialect using Dorzhiev's alphabet. ${ }^{117}$ According to the analysis of the situation of the east Siberian "natives" produced in 1923 for the local branch of the Geographical Society by an author from Buriatia, the current perceptions of the Buriat nation were fully in line with what the Zhamtsarano-led group had been arguing since $1905 .{ }^{118}$

While assuming leadership positions in the Commissariat of Education, the Buriat scholars discussed here continued their research and set up several scientific institutions-most important, the Learned Committee of the Buriatia-Mongol ASSR headed by Baradiin. Zhamtsarano became head of the Learned Committee of Mongolia. Both committees maintained close ties with scholars in Leningrad. Together they propagated the greatness of Buddhism and its compatibility with the modernizing goals of the new regime. ${ }^{119}$ A major event in the promotion of Buddhism in the early Soviet period was the first Buddhist exhibition in Petrograd in 1919 under the auspices of the Asiatic Museum of the Academy of Sciences. The nature of the exhibition was unprecedented; the organization of something similar in the tsarist period would have been unlikely. The exhibition's aim, as articulated by $\mathrm{Ol}^{\prime}$ denburg, was to disseminate among the masses the understanding of Buddhism "as one of the greatest belief systems that humankind has ever known." 120 Objects used in the religious services were exhibited in Petrograd not for their artistic quality but to convey to the public various aspects of the "Buddhist worldview" and the richness of the Buddhist heritage across space and time. ${ }^{121} \mathrm{Ol}^{\prime}$ denburg emphasized the role of Russian Buriats in the acquisition of the exhibited objects. ${ }^{122}$

The exhibition was accompanied by lectures delivered before large audiences by leading Russian Buddhologists in order to counter the representation of Buddhists as "idolatrous pagans" by conservative hierarchs of the

116 Koz'min, "Tuzemnaia intelligentsiia Sibiri," 75-78. See also K. S. Gerasimova, Obnovlencheskoe dvizhenie buriatskogo lamaistskogo dukhovenstva (Ulan-Ude: Buriatskoe knizhnoe izdatel'stvo, 1964).

117 Koz'min, "Tuzemnaia intelligentsiia Sibiri," 87; Otchet IV Plenuma Vsesoiuznogo tsentral'nogo komiteta novogo alfavita (n.p., 1931), 34-35. See also Robert Montgomery, The Late Tsarist and Early Soviet Nationality and Cultural Policy: The Buryats and Their Language (Lampeter, UK: Edwin Mellen, 2006), 238-53.

118 Koz'min, “Tuzemnaia intelligentsiia Sibiri," 84-87.

119 The idea that Buddhism was fully compatible with European learning and with the goals of the new Soviet regime, as articulated by Dorzhiev and supported by imperial scholars, took the form of the Buddhist renewal movement aimed at modernizing religious practices and customs among the Buddhists in the Soviet Union in the 1920s. See Gerasimova, Obnovlencheskoe dvizhenie, esp. 155-73.

120 S. F. Ol'denburg, "Pervaia buddiiskaia vystavka v Petersburge," in Ermakova, Buddiiskii mir glazami rossiiskikh issledovatelei, 213-29, here 215-16.

121 Ermakova, Buddiiskii mir glazami rossiiskikh issledovatelei, 212.

122 Ibid., 222, 224. 
Orthodox Church in the imperial period. ${ }^{123}$ Scholars spoke in exalted terms about the great traditions of Buddhism, assigning particular praise to datsans as centers of "not only religious but any cultural life" among the nomadic Mongols of Russia. Scholars offered profiles of "amazing" Buddhist lamas whom they had met, particularly lauding their "compatriot," the "famous Agvar Dorzhiev." 124 By the mid-1920s, Dorzhiev, Zhamtsarano, Ol'denburg, and Shcherbatskoi also ensured the resumption of services in the Buddhist temple built in St. Petersburg between 1909 and 1915 at Dorzhiev's initiative with crucial support provided by the Russian scholars. ${ }^{125}$

In the 1920s, Ol'denburg and Shcherbatskoi sharpened their criticism of Western methods of Buddhology and intensified their cooperation with representatives of the "living oral Buddhist tradition," 126 relying on Dorzhiev to facilitate their contacts with lamas from Buriatia, Mongolia, and Tibet. ${ }^{127}$ One of the strongest critics of European Buddhology was, in fact, Baradiin, who argued that the "essence [samoe sushchestvennoe] [of Indo-Buddhist culture] can be properly understood only if studied by Buddhists themselves" and criticized Western scholarship for its tendency to separate textual studies from the collection of ethnographic data on the life of Buddhist communities. ${ }^{128}$ An attempt to overcome this separation was the Institute for the Study of Buddhist Culture set up in Leningrad by Shcherbatskoi and Ol'denburg in 1927. The institute's stated aim was to study different aspects of Buddhist cultures through the cooperation of academics and lamas. ${ }^{129}$ The scholars declared the superiority of their own approach to the study of Buddhism elsewhere, particularly that of Thomas Rhys Davids's school of Buddhology in Britain. True to its declared "eastern orientation," the first academic partners of the new institute became the Learned Committees of Buriatia and Mongolia led by Baradiin and Zhamtsarano. ${ }^{130}$

\footnotetext{
123 Ibid., 215.

124 Vladimirtsov, "Buddizm v Tibete i Mongolii," 229-49.

125 Andreev, Khram Buddy v severnoi stolitse, 102, 110, 115.

126 Theodore Stcherbatsky, The Central Conception of Buddhism and the Meaning of the Word "Dharma" (London: Royal Asiatic Society, 1923); and his The Conception of Buddhist Nirvana (Leningrad: Office of the Academy of Sciences of the USSR, 1927). See also Ia. V. Vasil'kov, "Vstrecha vostoka i zapada v nauchnoi deiatel'nosti F. I. Shcherbatskogo," VostokZapad, no. 4 (1989): 193-203.

127 See Vladimirtsov's letter to V. L. Kotvich [Kotwicz], Archive of SPb IVR RAN f. 761, op. 1, d. 5, 1. 16.

${ }_{128}$ B. B. Baradiin, "Buddiiskie monastyri," in Ocherki istorii buriat-mongol'skogo naroda, ed. M. N. Bogdanov (Verkhneudinsk: Buriat-mongol'skoe izdatel'stvo, 1926), 109-10. See also Baradiin's letter to Shcherbatskoi of 7 June 1927, PF ARAN f. 725, op. 3, d. 34, 1. 17. 129 S. F. Ol'denburg, F. I. Shcherbatskoi, and M. I. Tubianskii, "Institut izucheniia buddiiskoi kul'tury," Izvestiia Akademii nauk SSSR, series VI, vol. XXI, no. 18 (1927): 1701-4. 130 Otchet o deiatel'nosti Akademii nauk SSSR za 1928 g. Obshchii otchet (Leningrad: Akademiia nauk SSSR, 1929): 88. See also Baradiin's correspondence with Shcherbatskoi,
} 
In the Caucasus, Marr unsurprisingly assumed the role of a champion of nation-building among the Abkhazians, helping opponents of unity with Georgia (a majority in the Abkhaz leadership and the emerging intelligentsia in the 1920s) to construct historical arguments in favor of separateness and superiority. ${ }^{131}$ The main scholarly institution to promote the cultural side of nation-building in Abkhazia became the Academy of Abkhaz Language and Literature set up in $1925 .{ }^{132}$ The very name of the new institution was invented by Marr, who also wrote the academy's statute. Marr's closest associate from prerevolutionary days, Chochua, became the academy's first chairman. ${ }^{133}$ The academy's activities were in line with the vision of Abkhazia as a key area in Marr's world of "Japhetic culture." The lack of an established literary tradition in the vernacular until the 1920s was pronounced a major strength of the Abkhazians, which aided the preservation of their unique prehistoric Japhetic past and enhanced their ability to make rapid cultural leaps at present and in future. ${ }^{134}$ The most significant argument for the future of nation-building, made by Marr when speaking before representatives of minority groups in the Caucasus in the 1920s, was about the "autochthonous" nature of their presence in the region. This idea became a formative element of much national scholarship in the Caucasus in the Soviet period and during the post-1991 independence. In post-communist identity politics in the Caucasus, Marr's authority is still evoked to buttress the argument in favor of the "autochthonism" of one or another nationality in the region. ${ }^{135}$

Influence also went in reverse. At the time of the establishment of the academy, Marr started to work on the elaboration of Charaia's above-mentioned hypothesis of the Abkhaz language's Japhetic nature and its greater antiquity in comparison with Georgian. ${ }^{136}$ The publication of Marr's grammar of the Abkhaz language in Leningrad was funded by the Abkhaz Council of People's Commissars to accelerate its appearance. ${ }^{137}$ Such support from elites of nonRussian minorities in the 1920s became for Marr an essential element in the

in which Baradiin outlines his perception of the institute's goals, PF ARAN f. 725, op. 3, d. 34, 11. 15-19.

${ }_{131}$ Marr played a similarly major role in nation-building in Azerbaijan. See, in particular, N. Ia. Marr, "Ob izuchenii Azerbaidzhana," PF ARAN f. 800, op. 1, d. 1837. See also his "Etnicheskaia i natsional'naia kul'tura Kavkaza," ibid., d. 1801; and "Akademiia nauk i izuchenie Kavkaza," f. 800, op. 1, ed. khr. 1409. Marr's position was subjected to strong criticism in Georgia. See, for instance, PF ARAN f. 800, op. 3, d. 333, 1l. 1-3.

132 A. M. Chochua, Sobranie sochinenii (Sukhumi: Akua, 1976), 3: 301.

133 Ibid., 118-19.

${ }^{134}$ Ibid., 297, featuring Marr's presentation at a meeting of the Abkhaz Commissariat of Public Enlightenment in October 1925.

135 Willem van Schenkel and Erik Jan Zuercher, Identity Politics in Central Asia and the Muslim World (London: Tauris, 2001), 24-25.

136 Ibid., 254. See also Marr, "Etnicheskaia i natsional'naia kul'tura Kavkaza,” 1. 9.

137 Chochua, Sobranie sochinenii, 3, 121. 
consolidation of his power base, with which he defended his theories from criticism by established linguists in Leningrad and Moscow. ${ }^{138}$

This story of the relationship between Russian imperial scholars and the first generation of the nationally minded intelligentsias discussed here ended tragically, particularly for the latter. The change of policies in the late 1920s underscored the differences in the positions and assumptions of the imperial Orientologists and members of the first generation of non-Russian national elites, on the one hand, and of the central Soviet leadership, on the other. Many members of local elites lost their leading positions in the ethnic autonomous regions and perished in the purges of the 1930s. By the second half of the 1930s, very few of the Russian scholars discussed here, who had established careers before the Revolution, were alive. One of those few was Shcherbatskoi (d. 1942) who, because of his age and status as academician, was not prosecuted. The academic school that he set up on the principles outlined above was destroyed, however. His younger academic associates in Leningrad-as well as Dorzhiev, Baradiin, and Zhamtsarano-were arrested at this time and linked to the same NKVD investigation. ${ }^{139}$

\section{Conclusion}

At the turn of the 20th century, Russian Orientologists had already articulated the ideological foundations of what Hirsch called "the double assimilation"- the assimilation of a diverse population into nationality categories and, simultaneously, the assimilation of those nationally categorized groups into a unified multi-ethnic state with the expectation that the former process would reinforce the latter. ${ }^{140}$ Scholars have noted that the Bolsheviks never fully explained why policies that clearly strengthened minorities' own particularistic identities at a sub-state level would contribute to the unity of the Soviet Union. ${ }^{141}$ This article shows the origins of the idea that sub-state ethno-national identities, fostered from above if necessary, would benefit state unity. The Bolsheviks' assumptions thus emerge as part of a tradition dating back to the "small homeland" ideology of the 1870s and 1880s, which rested on the view that a sense of belonging and loyalty to the entire fatherland in a country of Russia's size and diversity could be based only on strongly developed local identities which, as Orientologists had maintained

138 Even following Stalin's condemnation of Marr's theories in 1950 and the subsequent reluctance of scholars in the center to cite Marr's works, he remained a hero in Abkhazia. See for instance, Khvartskiia, Andrei Maksimovich Chochua.

139 Andreev, Khram Buddy v severnoi stolitse, 160. See also Vasil'kov, "Vstrecha vostoka i zapada," 203-9.

${ }_{140}$ Hirsch, Empire of Nations, 14.

141 Terry Martin, "Modernization or Neo-Traditionalism? Ascribed Nationality and Soviet Primordialism," in Stalinism: New Directions, ed. Sheila Fitzpatrick (London: Routledge, 2000), 354. 
since the 1890s, could be culturally distinct. The "small homeland" ideology, as the Orientologists interpreted it, also emphasized the formative role of the elites in fostering sub-state ethno-cultural national identities, a view to which the Bolshevik leaders in turn subscribed.

The extrapolation of the "small homeland" ideology onto the eastern and southern minorities was Russian intellectuals' response to nationalism within the framework of a highly diverse imperial state. The fact that an overarching identity was closely linked to the state rather than being ethnically Russian lent feasibility to the argument that loyalty to one's own cultural homeland was a solid building-block in the creation of a pan-Russian identity. The imperial scholars themselves constituted an ethnically heterogeneous group whose own overarching identity was state-framed Russian. To feel like Russian patriots they did not need to forget their mother tongue, be it German, in Rozen's case, or Georgian, in Marr's. In effect, they extrapolated both the "small homeland" ideology and their personal experience onto the peoples they studied. It is understandable that these views appeared realistic to the Bolshevik leadership, which was similarly multi-ethnic in origin and united in its belief in the supremacy of the state.

This article raises two further general issues, namely the role of imperial knowledge in the emergence of national movements in the empire's colonies or borderlands and the agency of representatives of the colonial periphery in the cultural politics of empire. As elsewhere in European empires, in Russia Orientalist knowledge played a highly important role in the production of the imaginings of eastern minorities as distinct nationalities and nations. In addition, in a move which seems unusual in a European imperial context, Orientologists consciously began to stimulate the emergence of nationally minded intelligentsias among these minorities at least two decades before the Soviet government initiated a major project of national construction. The prerevolutionary networks of imperial scholars and their local associates and the perceptions developed within those networks about local ethnic communities as ethno-cultural nations, in the case discussed here, had a significant impact on the Bolshevik policies of natsional'noe stroitel'stvo in the 1920s. These networks were also responsible for introducing elements (most notably religious) into sub-state nation-building, which ultimately proved incompatible with how the Soviet government saw the long-term goals of their modernization project.

The Russian case is also important for theorizing the agency of the colonized subjects in the production of European knowledge. In Russia, as in other colonial contexts, imperial scholars largely determined the categories and usually suggested the approaches through which the histories and cultures of the colonized were to be understood. At the same time, again as was the case elsewhere, scholars' perceptions were profoundly influenced by their local associates. Indeed, by 1905, the influence on imperial scholars of 
their former inorodtsy students became so significant that, in the days of the first Russian revolution, the imperial scholars often acted as mere mouthpieces of their inorodtsy associates, uncritically reproducing their views. The knowledge of the Russian eastern and southern periphery was thus coproduced by imperial scholars and representatives of the inorodtsy.

So, can we really apply to the case discussed here a widely accepted argument about the profound inequality between imperial scholars and "learned natives" and about the "hierarchical" nature of the knowledge the two groups produced? Russian imperial scholars themselves would give a negative answer to this question. They argued that they aimed to turn their inorodtsy associates into scholars in their own right and, particularly in relation to the study of Buddhism, that they were willing to utilize local traditions of scholarship and interpretation. According to the imperial scholars, such an approach demonstrated the superiority of Russian scholarship over that of their Western counterparts. ${ }^{142}$ Even if exaggerated, this claim by Russian imperial scholars was not without foundation. In the context of European scholarship of the time, Russian Orientologists such as Marr, $\mathrm{Ol}^{\prime}$ denburg, and Shcherbatskoi were particularly radical and systematic in their criticism of the domination of textuality in studying "eastern" cultures and of the Eurocentric belief in the superiority of European epistemology. Indeed, in their works published in the first two decades of the 20th century, these scholars anticipated by some 40 years the methodological revisions in Orientology in the West. ${ }^{143}$ This revisionism helped facilitate a certain parity between these Russian scholars and their local associates, which was unusual in the European colonial context of the time.

School of Languages, Linguistics, and Cultures

University of Manchester

Oxford Road

Manchester M13 9PL

United Kingdom

vera.tolz@manchester.ac.uk

$142 \mathrm{Ol}^{\prime}$ denburg, "Pamiati Vasiliia Pavlovicha Vasil'eva," 544-48; Ol'denburg et al., "Institut izucheniia buddiiskoi kul'tury," 1701-4.

${ }^{143}$ On the anticipation of Edward Said's critique of Orientalism in Sergei Ol'denburg's writings, see Tolz, "European, National, and (Anti-)Imperial," 129-34. For similar developments, but with different outcomes, in the German and Austrian scholarship in the period discussed here, see Marchand, "The Rhetoric of Artifacts," esp. 129-30. On the lateness of the revisions of Buddhist Studies in Western scholarship along the lines tentatively suggested by the Russian scholars, see Lopez, ed., Curators of the Buddha. 